\title{
Between fairness, welfare and feasibility: an approach for applying different distributive principles in transport evaluation
}

\author{
Geert te Boveldt ${ }^{*}$, Imre Keseru and Cathy Macharis
}

\begin{abstract}
Background: For assessing the desirability and feasibility of major transport projects decision makers often recur to ex-ante evaluation methods such as cost-benefit analysis or multi-criteria analysis. In these methods projects are evaluated for their impacts on the welfare of society as one indivisible entity. The use of these methods is limited for assessing socio-spatial equity, as costs and benefits of transport are unequally spread over space and society. Moreover, in projects that cross political borders these methods poorly represent the spatially differentiated interests of the decision makers.

Methods: This article proposes a novel evaluation approach, applied in a study on the possible demolition of a motorway linking the three Belgian regions of Brussels, Flanders and Wallonia.

Results: The application demonstrates how the social and spatial differentiation of effects can be evaluated, allowing to differentiate impacts for crucial stakeholders or criteria, but also to aggregate evaluation results in cases where pursuing supra-local or common interests is appropriate.

Conclusions: Whether and where decision making in transport should follow utilitarian or egalitarian distributive principles depends on context and political considerations. The presented approach allows decision makers to apply both principles where they are deemed appropriate, transparently, in a single project.
\end{abstract}

Keywords: Transport, Appraisal, Evaluation, Utilitarianism, Egalitarianism, Equity, Cost-benefit analysis, Multi-criteria analysis

\section{Introduction}

Decision making in major transport projects is often supported by an ex-ante appraisal or evaluation procedure. Still, mainstream evaluation methods are controversial, as budget overruns, underperformance, unintended effects, lock-ins, decision-making deadlocks and subsequent delays continue to be typical characteristics of major projects $[13,14,23]$. Especially cost-benefitanalysis (CBA), the dominant (and often obligatory) evaluation method, is criticised for its inability to

* Correspondence: geert.te.boveldt@vub.be

MOBI Research Group, Vrije Universiteit Brussel, Pleinlaan 2, 1050 Brussels, Belgium

\section{Springer Open}

prevent these pitfalls, even though many guidelines for a 'correct' application exist [5, 19, 41, 50].

Most criticisms on evaluation do not target the shortcomings of current methods in assessing the technical or socio-political feasibility of projects, but rather the way in which the methods assess the societal benefits of projects. This especially concerns the roots of current evaluation practices in positivist rationality and utilitarian ethics $[9,43,66]$. As the ultimate goal of evaluation is to distinguish 'good' from 'bad' decisions [3], evaluation methods are inevitably rooted in an ethical framework. Utilitarian ethics of distribution, favouring actions that generate the greatest good for the greatest number of people, is considered useful as a guiding principle, but as not sufficient as the sole ethical principle to assess the
(0) The Author(s). 2020 Open Access This article is licensed under a Creative Commons Attribution 4.0 International License, which permits use, sharing, adaptation, distribution and reproduction in any medium or format, as long as you give appropriate credit to the original author(s) and the source, provide a link to the Creative Commons licence, and indicate if changes were made. The images or other third party material in this article are included in the article's Creative Commons licence, unless indicated otherwise in a credit line to the material. If material is not included in the article's Creative Commons licence and your intended use is not permitted by statutory regulation or exceeds the permitted use, you will need to obtain permission directly from the copyright holder. To view a copy of this licence, visit http://creativecommons.org/licenses/by/4.0/. 
desirability of projects $[2,66]$. Moreover, as argued later in this article, a utilitarian framework is often inadequate for assessing the socio-political feasibility of projects.

As the cost and benefits of transport are unevenly spread over space and society, thus creating 'winners' and 'losers' [35, 52, 68], a utilitarian framework is inappropriate for evaluating projects in terms of social justice, fairness or equity [10, 29, 32, 44, 49, 65, 67]. In recent years, a discussion has emerged on the adequacy of alternative principles of distribution $[44,49,67]$.

While issues of equity have become a prominent topic in the field of transport studies, an appraisal method that adequately reflects these issues does not yet exist [18]. The goal of this article is therefore to propose an approach for evaluating the desirability and feasibility of transport projects, taking into account the unequal distribution of impacts over space and society, and allowing for the application of different distributive principles.

In this article we first discuss the challenges resulting from the unequal distribution of benefits and costs, as well as the arbitrations needed for determining the fairness and impacts on welfare of projects. This is followed by a discussion on the challenges of evaluating sociopolitical feasibility, considering the collaborative structures between actors or institutions needed for major transport projects.

Building on these insights, we propose a novel evaluation approach that addresses these issues. The goal is not to provide a new evaluation method per se, but to propose a structure for applying existing (participatory) methods, such as multi-criteria analysis or multi-actor multi-criteria analysis [38], for the evaluation of transport projects, taking issues of socio-spatial equity and socio-political feasibility into consideration. In principle, the approach can be followed for the evaluation of any transport project, but it is especially intended for projects where the uneven sociospatial distribution of impacts impedes the planning process. For this reason, the approach is demonstrated with a case study situated in a politically complex context, i.e. the reconfiguration of a motorway connecting Belgium's capital region, Brussels, with the two other Belgian regions, Flanders and Wallonia.

\section{The unequal distribution of benefits and costs over space and society}

Whether a person benefits from a specific transport project depends on many factors and individual characteristics, such as place of residence, work and other activities, physical and cognitive capabilities, income, gender, cultural preferences, etc. A new transport link, for example, might be desirable for those in need of better accessibility in the places that it connects, but undesirable for neighbouring residents who only experience the noise and pollution it generates. It can even be argued that in projects that do not produce immediate nuisance, some groups are relatively disadvantaged by the fact that public funds are spent on infrastructure from which they do not benefit. Also, the different aspects of sustainability (environmental vs. social vs. economic) are often conflicting $[6,12]$.

As their costs and benefits are unevenly distributed over society, space and time, transport projects are hardly ever pareto-efficient [67], which implies that they virtually always (re) produce winners and losers $[45,52$, 68]. As a consequence, we can understand transport projects as redistributive mechanisms of value over space. Consider, for example, a railway line between two cities (Fig. 1), that crosses the territory of a third city, but where it does not call. Whether the net societal value of the infrastructure is positive or negative depends wholly on the spatial scope of evaluation, depending on whether effects are measured for the entire project area or only for individual jurisdictions.

Conventional evaluation procedures such as CBA do not take socio-spatial impact differentials into account, as costs and benefits for society as a whole are aggregated into a single value $[52,54]$. This approach assumes Kaldor-Hicks efficiency, i.e. the principle that the negative effects on one group will be compensated by positive effects on another group [11] or in other words, the costs for the losers can be paid with the benefits for the winners. Critics on current evaluation practices target this principle, arguing that the Kaldor-Hicks compensation principle rarely functions in reality [66].

In projects that cross political borders, achievement of Kaldor-Hicks efficiency is even more unlikely, as it requires compensatory transfers between different political entities. Theoretically the advantages and disadvantages of transport projects vary from person to person, so capturing the full spectrum of impacts is practically unfeasible. Several authors therefore suggest to specify impacts for particular groups or particular areas [18, 45]. As this approach allows for mapping the distribution of costs

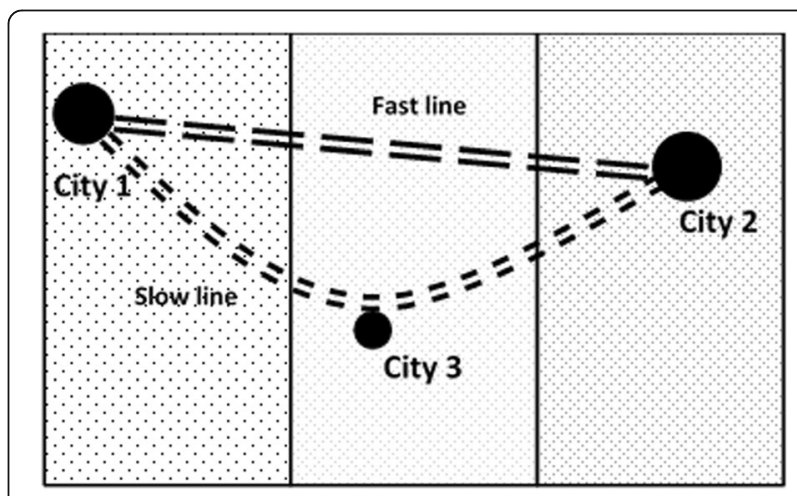

Fig. 1 The assessed desirability of the the alternatives depends on the perspective and scope of evaluation. Figure by author 
and benefits, it can also be useful in indicating the entities between which compensatory transfers are to be made to ensure Kaldor-Hicks efficiency.

\section{Measuring desirability: between welfare and fairness}

Much criticism on standard appraisal practices concerns the underlying positivist rationality, i.e. the framing of transport problems as technical, requiring a neutral or objective evaluation by experts, in order to make rational decisions $[1,22,33]$. In CBA especially, the method of willingness-to-pay or willingness-to-accept as means to derive weights for the relative importance of nonmonetary effects is contested, especially for the possibility of mismatches between economic demand and societal demand $[10,65,66]$.

Standard applications of CBA, but also of MCA, have their foundations in utilitarian ethics of distribution [54, $55,66]$, which prescribes maximising the sum of benefits for all members of society; the social optimum. This implies that among a set of alternatives, a 'just' decision means choosing the alternative that generates the highest increase in welfare for all members of society combined. Yet, as discussed above, a performance of a project alternative in terms of welfare depends on the scope of evaluation (area, period, population), and as a consequence, so does the answer to the question of whether a decision is good or bad. Whether the expansion of an airport, for example, is a good decision, largely depends on if the perspective of evaluation is national (better connections vs. costs), local (jobs vs. noise), global (climate change), or foreign (competition with own airport).

The fact that transport projects redistribute value over space implies that the interests of different groups of people at different places at different spatial and temporal scales need to be traded off against one another. By assessing the desirability of an alternative with a single indicator, the evaluator explicitly or implicitly makes a choice to be concerned with a specific area and its population.

Several scholars advocate the application of alternative distributive ethics, which do not simply prescribe the maximisation of welfare, but also a fair distribution of this welfare $[10,36,39,44,49,65]$. Most of these are based on the egalitarian ethics of distribution, such as developed by Rawls [51], which holds that maximising welfare for some should not entail the suffering of others $[36,39,66]$. For decision making, 'fairness' can be understood and operationalised in different ways, but the arguably most straightforward manner is the application of the maximin principle, which prescribes the decision alternative that maximally increases the minimum level of welfare for those who have least; the maximin principle [51]. An evaluation approach that considers fairness should therefore indicate the distribution of benefits and burdens over the relevant stakeholders.

When planners aim to maximise the total cost-benefit ratio for all members of society, i.e. maximising welfare according to the utilitarian principle, they inevitably need to sacrifice the interests of certain groups, but the extent to which this is acceptable is a political and moral question. For example, when aspiring a 'sustainable' society that requires minimal use of unrenewable resources (the long-term social optimum), to what extent should individual travel or consumption be restricted? As ([27], p. 231) puts it: "In complex alternative selection problems, in which multiple objectives and multiple criteria predominate, the notion of an "objective, "scientifically optimized, "best" alternative is a fallacy". On the other hand, as transport projects are hardly ever paretoefficient, a strict application of the egalitarian principle (i.e. projects with no negative effects for certain groups) is impossible [66].

For example, the fast line in Fig. 1 has a high aggregate net value for the population of the entire project area, but when separate evaluations are performed for each of the cities' administrative territories, we see that that the value is unequally distributed and that city 3 experiences a negative net impact (Fig. 2). Another option would be to build another, slower, railway line that also calls in city 3 . The societal value is fairly evenly distributed over each of the territories, but the total aggregate value is lower than that of the fast line. Whether the nuisance experienced in city 2 is worth the benefits for society as a whole, or if the slow route is preferable depends on the applied politics or ethics of distribution.

As a preliminary conclusion, we can argue that a decision maker intending to optimise the welfare performance of a project needs to make arbitrations on three levels: 1) between the different components of utility, 2) between the interests of people in different places and scales in both space and time, and 3) between the different ethical principles for a fair or just distribution of welfare over society (Fig. 3).

\section{Measuring feasibility: the need to reflect the interests of decision makers}

While many authors are concerned with the substantive purposes of appraisal, i.e. relating to the quality of the decision, few are concerned with the instrumental purpose, i.e. the role of evaluation in facilitating a decision's implementation [21, 62].

If a project is evaluated with the aim to inform decision making, it is logical that the parameters within which a project is to be optimised reflect the interests of the decision maker. In practice this often means that a project's desirability is assessed for the territory 


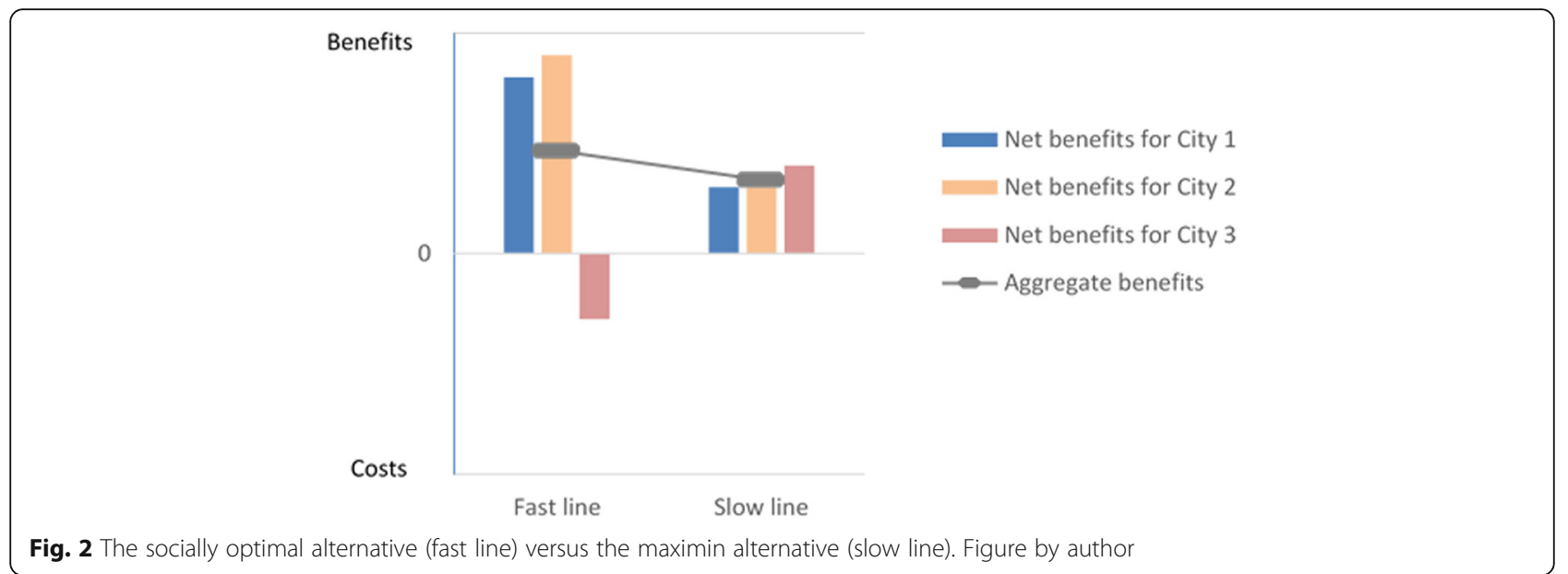

administered by the authority that commissions the evaluation. We can argue that if the project's success depends on other actors whose interests fall within a different socio-spatial scope, as a consequence, a singleactor desirability assessment provides a poor indication of the project's feasibility in terms of social or political support. We can argue that this is a common situation in transport, which by nature consists of lines and networks, while the organisational structure of space is territorial. The spatial discrepancy between transport networks and territorial government exists on several levels of scale and complicates the planning and governance of inter-jurisdictional connections or networks, such as international corridors [53] or functional urbanarea wide networks [57].

In addition, many authors stress the fact that major transport projects do not only cross geographical borders,

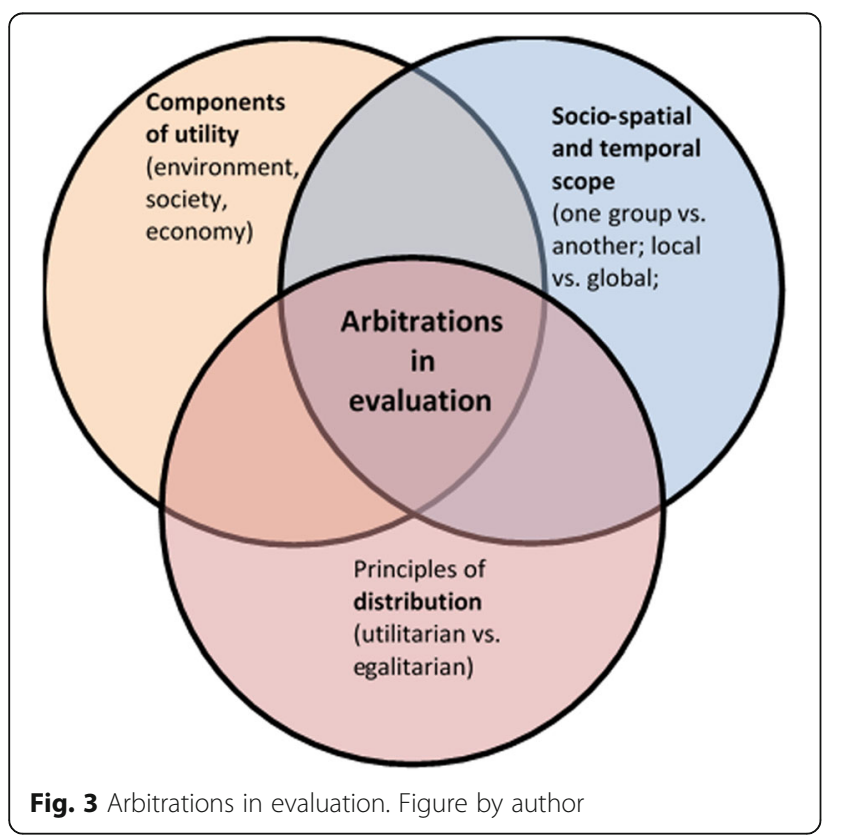

but also the virtual borders between the different public institutions of different governmental levels, as well as between the public, civic and private sectors. Single-actor led top-down planning practices are becoming increasingly rare and various forms and degrees stakeholder participation become the norm, be it either for substantive or instrumental purposes (e.g. [26, 28, 31, 56]).

It can be argued that whether in a feasibility assessment an actor is relevant or not depends on the role it plays or can play facilitating or obstructing the project. Institutional actors typically have legal competences in a project through laws or permits, which means they have the individual power to block the project. Stakeholders from other domains, such as companies or civic organisations can also have the competence to 'make or break' a project, even though in many cases their support is needed as a group rather than as individual actors. We can infer that the specification of impacts by socio-spatial groups also pertains for the assessment of a project's feasibility.

\section{Representing individual or collective interests}

The previous sections discussed the rationale for the specification of impacts by stakeholder or by territory, allowing for an approximation of the socio-spatial distribution of advantages and disadvantages, providing a better indication of a project's feasibility if it depends on multiple actors, especially if their interests comprise different areas or spatial scales. Specifying impacts allows a decision maker to reveal its concern with the interests of relevant social groups or stakeholders and to identity disproportionate negative impacts and thus assess the fairness of a project according an egalitarian principle of distribution and identify the best alternative according to Rawls's maximin principles.

This is not to say that the social optimum principle is without use in decision making. As transport projects typically require consent of multiple actors, they are vulnerable to collective action problems that emanate from 
the discrepancy between individual and collective interests. This problem has been the subject of study in several subfields of political sciences, such as actor-centred institutionalism [59], multi-level governance [30], (institutional) collective action theory [20, 46-48] and metropolitan governance $[4,25,60]$.

Although De Vries and Priemus [15] argue for an area-based approach, which integrates the interests of different policy sectors, different countries (or other independent territories) and different scales for a specific area, the potential role of evaluation to address collaborative decision-making issues has received little attention thus far. Projects that favour common, global interests, often meet resistance from local actors who are or feel (disproportionally) disadvantaged; the socalled not in my backyard (NIMBY)-effect [17, 24, 70]. While this phenomenon is typically associated with residents resisting public projects, we can argue that the identical mechanisms hold for local institutions opposing higher-scale projects that are not in their interests.

The scalar mismatch between decision problem and authority leads to a classic collective action problem: actors do not experience the negative or positive impacts beyond their spatial boundaries, so-called spillover effects, and are therefore unlikely to act in favour of the public good [46-48, 59]. Similar effects occur in a temporal dimension, when elected officials allocate their budgets for short-term gains only.

A common consequence of this problem is the joint decision trap [58], that is, a situation where instead of the socially optimal solution the lowest common denominator is chosen, i.e. the solution that requires the least sacrifice from any of the individual actors (the slow line in the example of Figs. 1 and 2). While the joint decision trap is usually referred to as an undesirable situation in politics, we can argue that it corresponds to an ideal distribution from an egalitarian point of view, as opposed to the social optimum that corresponds to the utilitarian ideal. The question here is: what amount of local harm is acceptable in favour of the greater good?

The choice of the appropriate equilibrium between utilitarian and egalitarian solutions is both political and context- specific. Also, the degree of decision autonomy of local actors is context-specific. We can conclude that an evaluation approach would make a valuable contribution if it allowed decision makers to assess the performance of projects based on both types of distributive ethics, as a base for negotiation and to make choices transparent for citizens. This means that in an evaluation procedure, first the desirability of projects for individual, local actors must be assessed, to gauge the acceptability of the project on a local level. Next, the aggregation of individual results can provide an indication of the social or area-based optimum.

\section{Dealing with institutional levels and spatial scales}

Complex transport projects typically imply multiple decision makers of various institutional levels [53]. Hooghe and Marks [30] refer to this context as a multi-level governance situation, implying the absence of a top-down decision hierarchy between the various institutional levels, necessitating continuous negotiation between the levels [30]. Typical examples are projects that cross state borders and are therefore subject of both national and international (e.g. European Union) governance, or within federal states such as Belgium, where many transport projects require cooperation between the national and the regional or even the municipal level. As a consequence, in multi-level governance situations, the scope of interests of actors are differentiated not only in terms of place, but also in terms of scale.

When we consider a situation with two levels of government (Fig. 4), assuming that each government optimises its policy in favour of the interests of its own area (the local optimum), the higher-level (e.g. the federal) government is the most likely to pursue supra-local, common interests. The outcome of an evaluation performed from the perspective of this actor would therefore be closest to the social or the area optimum. Still, for reasons of fairness and feasibility (identifying the likelihood of local resistance), evaluation outcomes from the perspectives of lower-level entities (e.g. regions) are valuable too. Moreover, aggregating the preferences of local actors provides the interesting possibility of approximating the social or area optimum through a different angle.

\section{The approach}

As in conventional evaluation, the approach that we propose starts with the definition of the problem and project alternatives, but the remaining of the procedure includes three additional steps:

1. Selection and classification of stakeholders This step concerns the identification and classification of stakeholders that are considered relevant in the project. While conventional evaluation departs from the principle that impacts are universal, the inclusion of stakeholders implies that impacts are specific to place and type of stakeholder. The goal here is not to present an extensive stakeholder-mapping framework, especially since many different methods already exist (see e.g. [7]), but within the scope of this article, a rough selection and classification can be made following the principles of socio-spatial fairness (who are the stakeholders among whom an egalitarian distribution of benefits and burdens is to be ensured?), and socio-political feasibility (who are the 


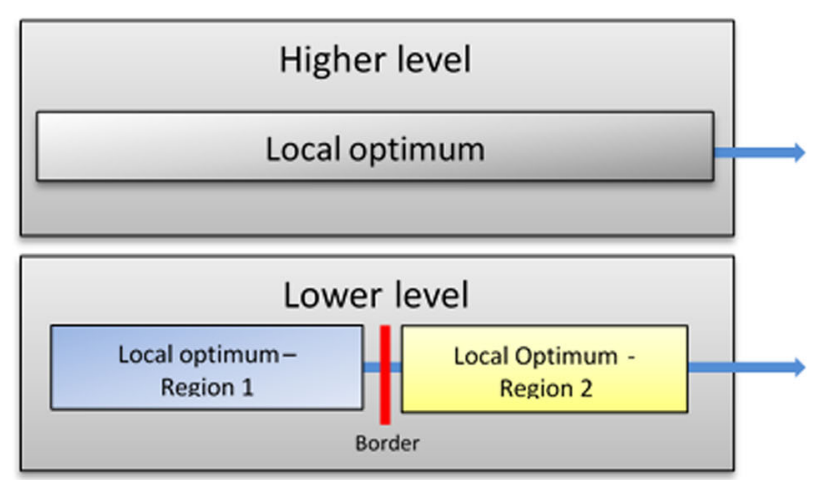

Approximation of area optimum through representation by high level authority

Approximation of area optimum by aggregation of local optima

Fig. 4 Identifying area optima in multi-level governance situations. Figure by author

stakeholder whose support or collaboration is necessary?).

2. Stakeholder-specific evaluation

This step concerns the evaluation of the project alternatives for each of the stakeholders individually. This step suits especially to evaluation methods from the MCA family, since contrarily to CBA, they provide the possibility to use stakeholder-individual evaluation criteria, such as in the various forms of participatory MCA (e.g. [16, 37, 38, 40, 61, 63]; see Fig. 5-2), where each stakeholder defines their own set of criteria and accords

1. Conventional evaluation (cost-benefit analysis, multi-criteria analysis)

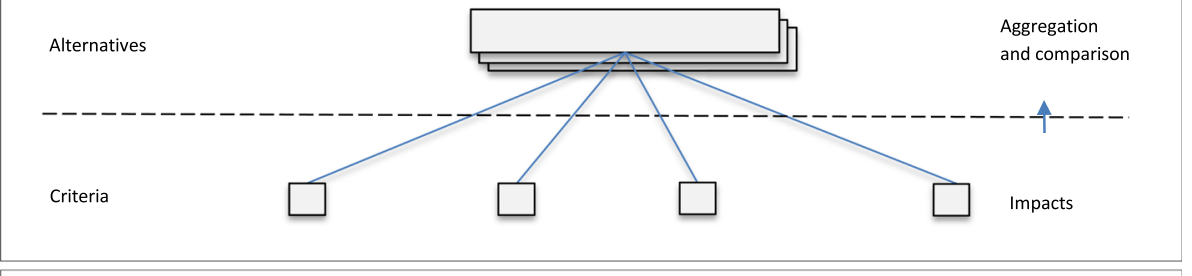

2. Multi-actor approach (e.g., Macharis, 2005; Stirling \& Mayer, 1999)
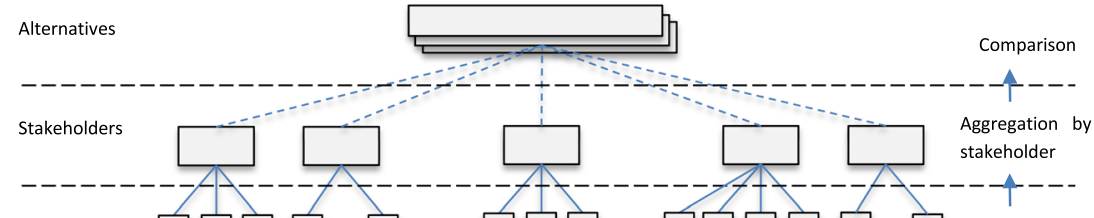

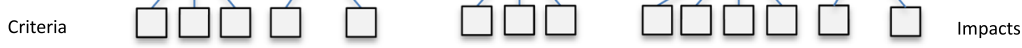

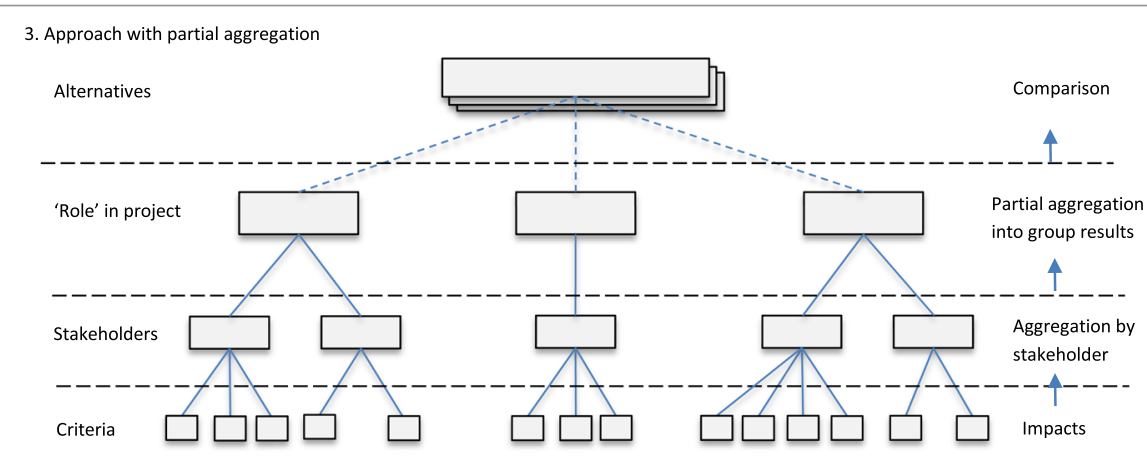

Fig. 5 The proposed approach with partial aggregation, in comparison to conventional evaluation and existing multi-actor approaches. Figure by author 
weights to each of them. This step allows the evaluator to incorporate stakeholder-specific interests in the evaluation and thus to assess stakeholderindividual impacts.

3. Partial aggregation into group results Apart from the so-called input-level aggregation approaches [34], which involves stakeholders, but no individual specification of either input or output (e.g. [7, 42]), existing participatory MCA approaches refrain from aggregating stakeholder results into a group output, as this raises many issues with regard to the relative relevance or power of the stakeholders $[38,63]$.

In the proposed approach, individual results are partially aggregated, which can be useful in various situations. In certain projects, the number and heterogeneity of the stakeholders might be so high that an analysis of each individual result might present too much complexity for the decision maker. Thus, partial aggregation makes it possible to handle large numbers of heterogeneous stakeholders, but it also allows for distinguishing the results for those stakeholders or stakeholder groups for whom the impacts need specific consideration. For example, to ensure the feasibility of a project, it is useful to consider the results for actors who are essential in the project (e.g. the authority issuing construction permits), as individuals, while other actors are not essential as individuals, but only as groups (e.g. investors, customers, clients, passengers, citizens).

In the second place, partial aggregation makes it possible to apply different principles of distributive ethics within one evaluation procedure. Where appropriate, aggregated stakeholder results can reveal socially optimal alternatives, aiding decision-making from a utilitarian perspective. Yet, by distinguishing the results for stakeholder groups with different 'roles' in the project (see Fig. 5-3), it is possible to verify if any of the groups is disproportionately affected, facilitating decision-making from an egalitarian perspective.

In a formal sense, the appropriate way of aggregation depends on the type of evaluation method being used. When MCA methods from the simple additive weighting (SAW) or weighted sum model (WSM) family are used (e.g. in $[29,63])$, results can be aggregated using the arithmetic mean of the individual scores. In non-compensatory non-relative MCA, however, where individual results can have both a positive and a negative dimension, aggregation consists of the separate summation of positive and negative impact scores.

\section{Application: evaluating the demolition of Brussels' largest elevated motorway}

In what follows, the approach is demonstrated by showing how it was applied in an actual inter-regional project. This section reports on the application following the consecutive steps of the approach.

\subsection{Definition of the problem and project alternatives}

The project concerns the possible demolition of an overpass that constitutes the longest elevated motorway in the urban area of Brussels, Belgium. The overpass, opened in 1973, serves as the main carrier for motorised traffic from the Southeast (Fig. 6) and is used by thousands of daily commuters from Flanders and Wallonia to Brussels. However, the overpass also represents a significant physical barrier in the urban landscape and generates various detrimental effects on the environment, such as noise and air pollution. Moreover, it is considered incompatible with the city's goals to stimulate a more sustainable modal split among commuters. Since the early 2000s, the possibility of demolishing the overpass has regularly been discussed, but the debate gained momentum in 2017 when severe damage was discovered in the concrete structure, which revealed that long-term maintenance of the overpass would require significant investments [8].

Following this event, the Brussels regional government expressed its intention to tear down the overpass, and on its behalf, the Brussels regional planning department started studying the possibilities for reconfiguration of the axis and the overpass. The authors of this paper worked in close concertation with the Brussels planning department, though they did not perform the evaluation on behalf of this institution.

In a political sense, the project is complicated due to the fact that the Belgian institutional landscape is characterised by a strong degree of decentralisation, in which the constituent regions of Brussels, Flanders and Wallonia have complete autonomy in terms of transport and environmental planning. Municipalities, of which there already 19 in the Brussels region alone, also have a significant say in local mobility and environmental matters.

The demolition of the overpass would have different impacts for Brussels, Flanders and Wallonia. While the demolition would benefit the direct environment in the Brussels region and in the municipality in which the overpass is located (Auderghem), the regions of Flanders and Wallonia would lose an important connection without on-grade crossings with the inner city of Brussels. The question is hence whether demolition of the overpass is a good idea, and if yes, how the space should be configured instead.

The project alternatives that were studied constitute three main groups: 1) alternatives in which the overpass is maintained, possibly with alterations of in the traffic situation on the boulevard under the overpass; 2) maintenance of the overpass, but closure for private motorised traffic; and 3) demolition of the overpass. 


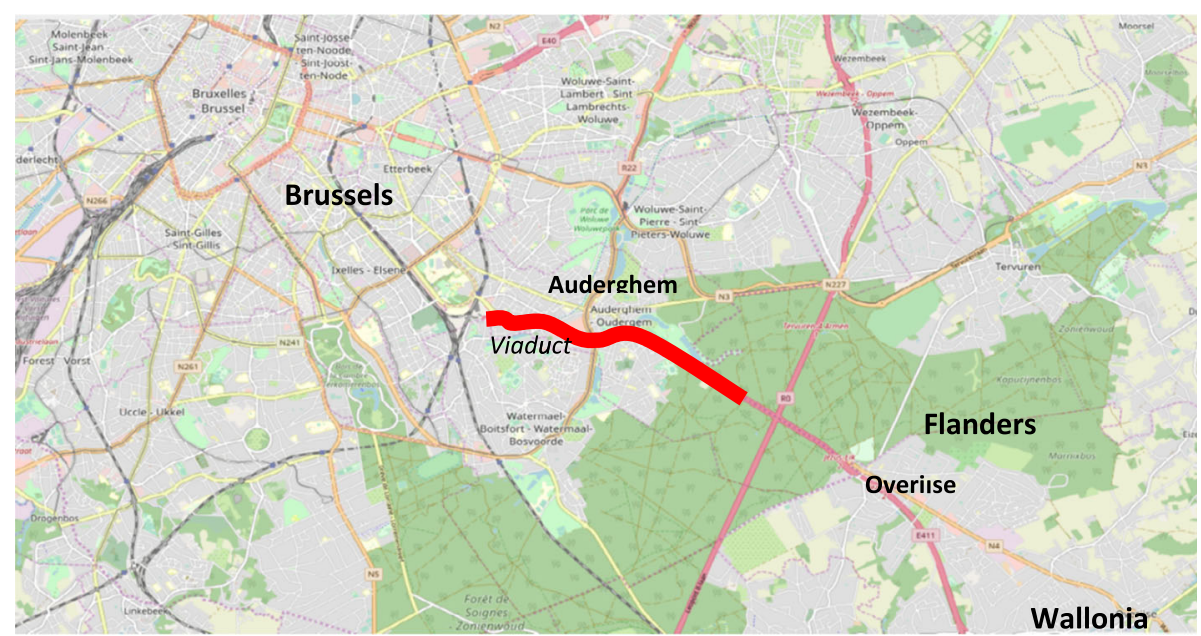

Fig. 6 Location of the viaduct in the Brussels region. Source: OSM, modified by author

\subsection{Selection and classification of stakeholders}

As the intention of the evaluation in the early planning stage was explorative rather than conclusive, it was decided to involve only a limited number of stakeholders, and to reserve a time and resource-intensive participation procedure for a later stage. As such, the goal was not to obtain an exhaustive representation of societal interests, but to focus on two principles. The first principle of selection was socio-political feasibility, which implies that support for the project is to be ensured among the stakeholders who have the legal, technical or financial competences to 'make' or 'break' the project, i.e. the actors that ensure the feasibility of the project. In the political context of Belgium, this implied the inclusion of institutional stakeholders of various administrative levels. The second principle that was followed is spatial fairness. Hence, for assessing whether the project would produce excessively negative impacts at a particular place, the authorities representing the various regions and municipalities that would possibly be affected, were included.

Figure 7 shows the classification of stakeholders. The project is an initiative of the Brussels planning department, which is the competent authority in urban planning matters (including design and construction permits) on the regional level, but as spatial impacts stretch beyond the regional borders, the equivalent institution in Flanders was consulted as well. Because of the overpass's function as a major transport axis, the Brussels regional mobility department plays a significant role in design, construction and maintenance. As the

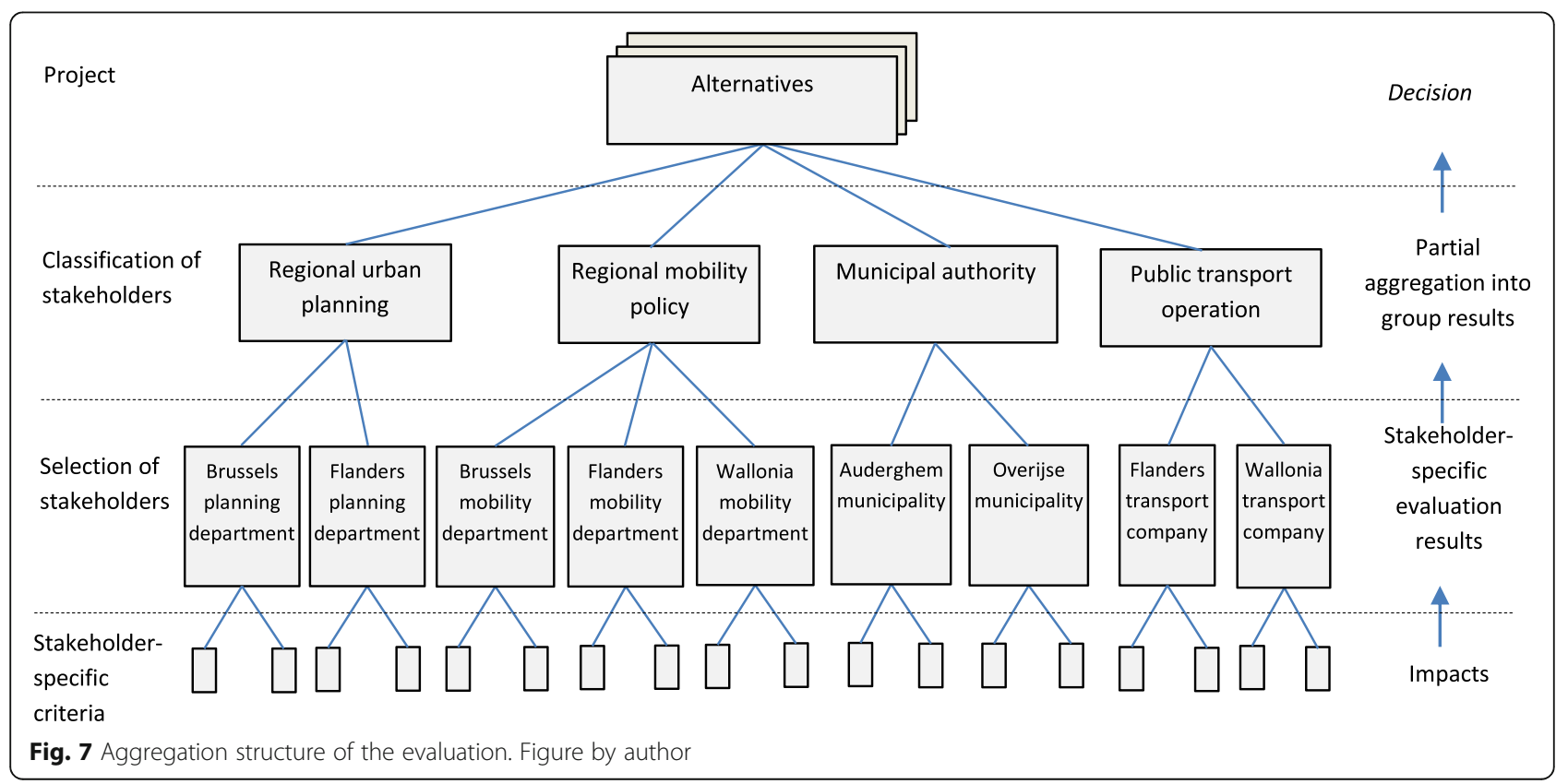


impacts in terms of mobility reach far beyond the regional borders, the equivalent institutions from the regions of Flanders and Wallonia were consulted too. In terms of local impact, the overpass is located within the confines of the Brussels municipality of Auderghem, but the bordering Flemish municipality of Overijse is also expected to be heavily affected by any type of reconfiguration. Lastly, as the overpass is an important axis for regional buses, operated by the Flemish and Walloon public transport companies, these actors were included too.

It must be noted that any stakeholder analysis is subjective and constrained by the available time and resources. This case study, for example, could have included representatives for residents or commuters, but as for practical constraints the number of stakeholders was limited, it was assumed that these groups were (at least to a certain extent) represented by the administrations of their respective regions or municipalities of residence.

\subsection{Stakeholder-specific evaluation}

In the presented case study, the stakeholders had the freedom to compose their individual list of evaluation criteria. It is important to note that special attention was paid to the spatial scale and scope of the criteria. For example, for the criterion 'generation of rat-running traffic' separate analyses were made for the regions of Brussels, Flanders and Wallonia.

For calculating stakeholder-specific performance scores of the alternatives, Non-compensatory Non-relative MCA was used (see [64]). A particular feature of this method is that positive and negative impacts are not used to calculate an overall, final score for each alternative, but that positive and negative impacts are kept distinct, which is useful in projects where the decision problem is not simply to choose one alternative out of a set, but to use evaluation results to incrementally improve the project. Another specificity of the method is that the scores of the alternatives do not, as in other types of MCA, express the performance of one alternative compared to the other alternatives, but compared to a baseline alternative (the current situation) instead. This procedure ensures that the performance score of an alternative is not affected by the scores of the other alternatives.

The research team gathered data used for assessing the effects of the alternatives for the criteria using a variety of sources and methods, including the local transport model used by the Brussels regional administration. The researchers presented these effects in terms as neutral terms as possible, after which the representatives of the stakeholders were asked to grade the effects on a 7 point scale ranging from 'very negative' to 'very positive'. In the next step, the representatives assigned relative weights to each of their criteria (ranging from 0 to 1 ) using the Simple Multi-Attribute Rating Technique [69]. Doing so, for each alternative and for each stakeholders an aggregate positive and an aggregate negative impact score was calculated, in which the maximum impact (negative or positive) equals 1.

As in the project presented here the initiating actor has formally decided to demolish the overpass, we will analyse this alternative in greater detail. Figure 8 shows the total positive and negative impact scores of this alternative for all actors. We observe that for the Brussels planning department, the initiator of the project, the assessed impacts are largely positive. This is also the case for the municipality of Auderghem, where the overpass is located, even though it is also expected to suffer minor negative impacts. For the regional mobility departments, public transport operators, and the municipality of Overijse, however, the evaluated impacts are mainly negative. Non-Compensatory Non-Relative MCA allows for showing both the negative and positive impacts of an alternative, as can be seen in the results of the alternative 'Demolition' for the Wallonia mobility department and the Flanders planning department.

For comparison, Fig. 9 shows the results for the least radical alternative, i.e. maintenance of the overpass, but implementing traffic calming measures underneath. Here we see that except for the regional mobility departments, impacts are much smaller. The public transport operators (who use the overpass and not the streets below) are not affected at all.

\subsection{Partial aggregation into group results}

Figure 7 shows the groups and the roles according to which individual results were aggregated. Figures 8 and 9 show the impact scores for the individual stakeholders, but also the aggregated scores for the stakeholder groups. We observe that within the groups 'planning departments' and 'municipalities' impacts are evaluated as mostly positive, even though for the stakeholders from Flanders (Flanders regional planning department, municipality of Overijse), impacts are mostly negative. Hence, for these stakeholder groups, the supra-local optimal choice would be to tear down the overpass. However, for the stakeholder groups 'regional mobility departments' and 'public transport operators', the impacts of this alternative are largely negative. We can conclude that if the decision maker deems the support of public transport operators and regional mobility departments necessary, the project must be modified in order to satisfy the requirements of these stakeholders.

It must be kept in mind that any evaluation method necessarily involves compromises between accuracy and practical feasibility. The results of this application too should be interpreted as indicative rather than 


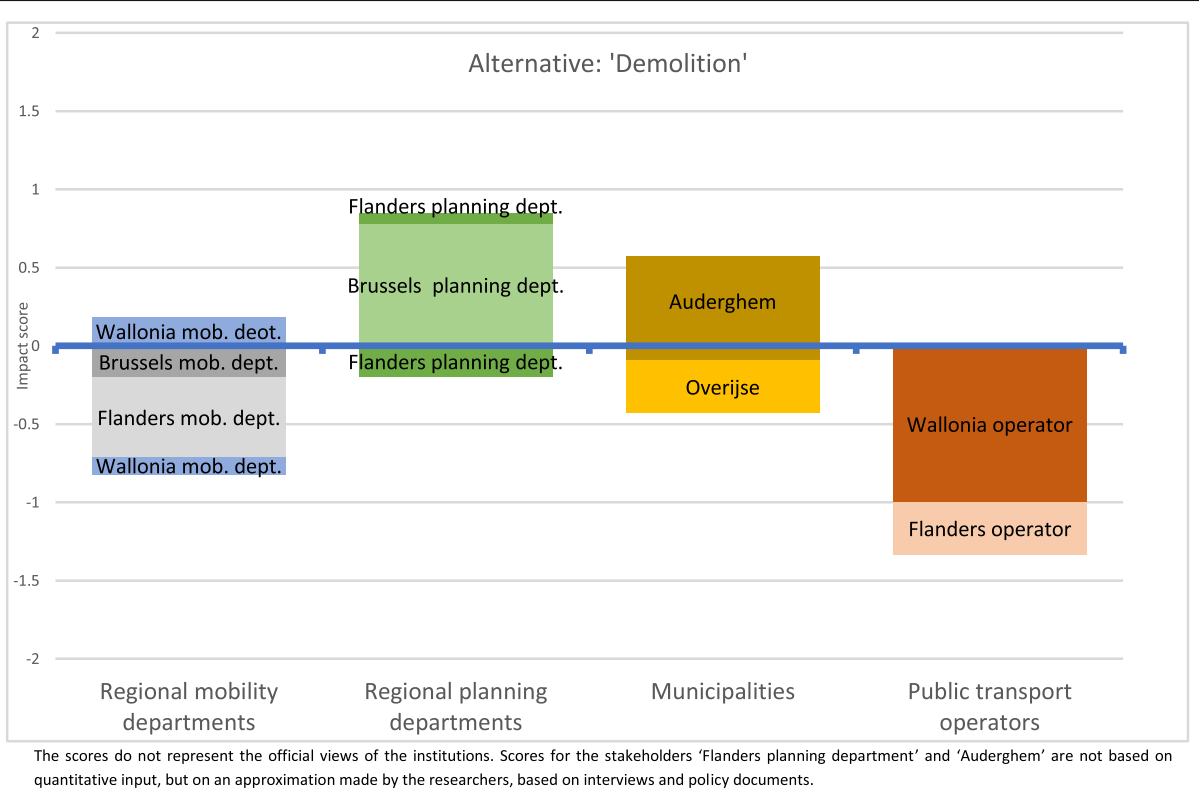

Fig. 8 Impact scores of the alternative 'Demolition'. (Maximum possible positive or negative impact for one stakeholder $=1$, resp. -1 ). Figure by author

conclusive. Bearing in mind the goal of this article, we have chosen to show only final impact scores for stakeholders, but an analysis of disaggregate scores on each of the stakeholder's criteria is also possible. Any MCA result is a combination of both 'objective' components (the data on effects, assessed by the evaluator), and subjective components (the choice of evaluation criteria and the relative weights of these criteria). In this particular case too, the selection and classification of stakeholders was bound by the specificities of the case as well as practical circumstances. For example, to include the interests of the surrounding inhabitants, different sorts of participatory processes could have been set up, but for practical reasons it was decided to only include the democratically

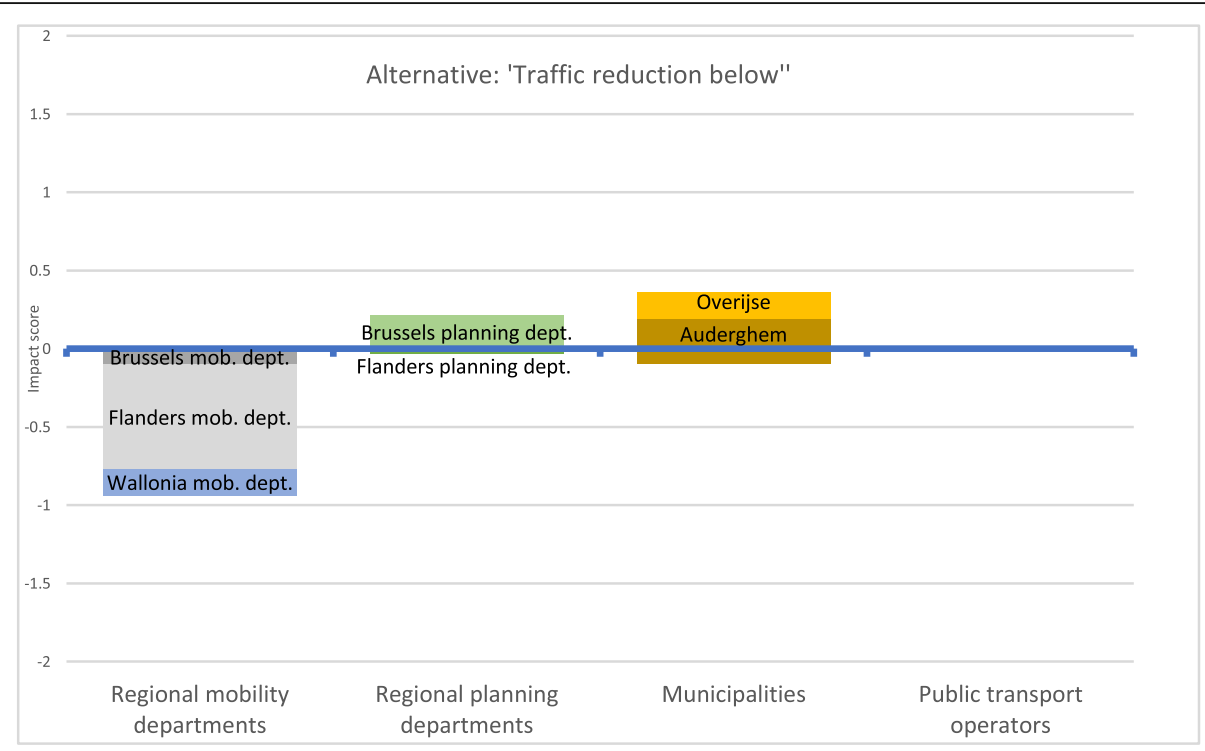

The scores do not represent the official views of the institutions. Scores for the stakeholders 'Flanders planning department' and 'Auderghem' are not based on quantitative input, but on an approximation made by the researchers, based on interviews and policy documents.

Fig. 9 Impact scores of the alternative Traffic reduction below'. (Maximum possible positive or negative impact for one stakeholder =1, resp. -1). Figure by author 
representative authorities, i.e. municipal and regional public administrations.

\section{Conclusion}

This article dealt with the challenges for decision making that emanate from the fact that the impacts of transport projects vary along spatial and societal dimensions and that any attempt to synthesise the societal value of a large project into a single indicator implies multiple arbitrations concerning the various components of utility, the spatial and temporal scope of evaluation, and modes of distribution of value over society.

The limitations of single-actor evaluation methods, such as conventional MCA and CBA, in dealing with the unequal socio-spatial distribution of effects have been documented extensively. A key concern is that conventional evaluation methods are based on the utilitarian principle of distributive ethics, which only takes into account the effect of transport projects on the welfare of society as an aggregate whole, without regard of the fairness of the distribution of this welfare over space and society. We argue that this is not only an issue for assessing societal desirability, but also for ensuring the socio-political feasibility of the project, which especially in in larger projects typically involve multiple institutional stakeholders.

This article therefore presents a novel approach that allows applying both the utilitarian and egalitarian principles of distribution within a single evaluation, so that alternatives can be assessed on how much they contribute to the total welfare within those stakeholder groups where it is appropriate, but that they can also be assessed on how fair the burdens and benefits are distributed between the different stakeholder groups.

The approach consists of three steps, added to the typical evaluation phases of determining the problem and the project alternatives. The first step is the selection and classification of stakeholders, either from the perspective social-political feasibility or from an equity point of view. The second step is the assessment of impacts on each of the stakeholders, allowing to take into the account the social and spatial differentiation of impacts. The third step is the partial aggregation of the evaluation results, which makes it possible to distinguish the evaluation outcomes for different stakeholder groups and to notice any possible disproportional impacts or disproportionally affected stakeholder groups. Yet, by aggregating the results of stakeholders that are considered equivalent, results can be obtained that not only reflect interests on the individual and local scale, but also on the common or supra-local scale, which is valuable in addressing collective action problems.

In theory, any MCA or other evaluation method that result in a rating or ranking of project alternatives can be used within the presented approach. Research on the suitability of the various existing evaluation methods for the application in political reality of transport planning would be therefore be valuable. This also counts for other practical elements of multi-actor evaluation, especially with regard to the time- and resource-intensive aspects of a participatory approach. Other issues to be addressed relate to the practical aspects of involving institutions or other stakeholders with strategic interests in the project and the possible modalities for dealing with strategic behaviour.

\section{Abbreviations}

CBA: Cost-benefit analysis; COMCA: Competence-based multi criteria analysis; MAMCA: Multi-actor multi-criteria-analysis; MCA: Multi-criteria analysis; SAW: Simple additive weighting; WSM: Weighted sum model

\section{Declarations}

The research for this article was conducted in the framework of the MOBRU research project, funded by the Brussels Institute for Research and Innovation (INNOVIRIS). The authors thank the representatives of the various organisations for their input that was used in the case-study discussed in this article: Perspective.brussels, Bruxelles Mobilité/Brussel Mobiliteit, Departement Mobiliteit en Openbare Werken, Ruimte Vlaanderen, Service Public de WalIonnie, the municipalities of Auderghem and Overijse, the transport companies TEC and De Lijn, but also the two anonymous reviewers for their comments.

\section{Authors' contributions}

The authors declare that they all contributed to the research for this article, drafting the manuscript and that they approved submission.

\section{Competing interests}

The authors declare that they have no competing interests.

Received: 20 December 2018 Accepted: 19 May 2020

Published online: 02 June 2020

\section{References}

1. Alexander, E. R. (2000). Rationality revisited: Planning paradigms in a postpostmodernist perspective. Journal of Planning Education and Research, 19(3), 242-256. https://doi.org/10.1177/0739456X0001900303.

2. Alexander, E. R. (2006). Evaluations and rationalites: Reasoning with values in planning. In Evaluation in planning. Evolution and prospects (pp. 39-52).

3. Alexander, E. R., \& Faludi, A. (1989). Planning and plan implementation: Notes on evaluation criteria. Environment and Planning B: Planning and Design, 16(2), 127-140. https://doi.org/10.1068/b160127.

4. Allmendinger, P., \& Haughton, G. (2009). Soft spaces, fuzzy boundaries, and metagovernance: The new spatial planning in the Thames Gateway. Environment and Planning A, 41(3), 617-633. https://doi.org/10.1068/a40208.

5. Annema, J. A., Mouter, N., \& Razaei, J. (2015). ScienceDirect cost-benefit analysis (CBA), or multi-criteria decision-making (MCDM) or both: Politicians' perspective in transport policy appraisal. Transportation Research Procedia, 10, 788-797. https://doi.org/10.1016/j.trpro.2015.09.032.

6. Banister, D. (2008). The sustainable mobility paradigm. Transport Policy, 15(2), 73-80. https://doi.org/10.1016/j.tranpol.2007.10.005.

7. Banville, C., Landry, M., Martel, J., \& Boulaire, C. (1998). A stakeholder approach to MCDA. Systems Research and Behavioral Science, 15, 15-32.

8. Belga. (2017, October 7). Viaduct Herrmann-Debroux deels gesloten door betonschade | BRUZZ. BRUZZ Retrieved from https://www.bruzz.be/videoviaduct-herrmann-debroux-deels-gesloten-door-betonschade-2017-10-07.

9. Beukers, E., Bertolini, L., \& Brömmelstroet, M. T. (2012). Why cost benefit analysis is perceived as a problematic tool for assessment of transport plans: A process perspective. Transportation Research Part A, 46, 68-78 Retrieved from https://ac.els-cdn.com/S0965856411001376/1-s2.0-S0965856411001376main.pdf?_tid=0907c134-da9a-11e7-bd0c-00000aab0f01\&acdnat=151257425 7_ca802159dae48f1682eb27716c162697. 
10. Beyazit, E. (2011). Evaluating social justice in transport: Lessons to be learned from the capability approach. Transport Reviews, 31(1), 117-134. https://doi. org/10.1080/01441647.2010.504900.

11. Boadway, R. W. (1974). The welfare foundations of cost-benefit analysis. The Economic Journal, 84(336), 926-939 Retrieved from http://www.jstor.org/ stable/pdf/2230574.pdf.

12. Boussauw, K., \& Vanoutrive, T. (2017). Transport policy in Belgium: Translating sustainability discourses into unsustainable outcomes. Transport Policy, 53, 11-19. https://doi.org/10.1016/j.tranpol.2016.08.009.

13. Bruzelius, N., Flyvbjerg, B., \& Rothengatter, W. (2002). Big decisions, big risks. Improving accountability in mega projects. Transport Policy, 9, 143-154. https://doi.org/10.1016/S0967-070X(02)00014-8.

14. Cantarelli, C. C., Flyvbjerg, B., Molin, E. J. E., \& van Wee, B. (2010). Cost overruns in large-scale transportation infrastructure projects: Explanations and their theoretical embeddedness. European Journal of Transport and Infrastructure Research, 10(1), 5-18.

15. de Vries, J., \& Priemus, H. (2003). Megacorridors in north-west Europe: Issues for transnational spatial governance. Journal of Transport Geography, 11(3), 225-233. https://doi.org/10.1016/S0966-6923(03)00033-4.

16. Dean, M., \& Hickman, R. (2018). Comparing cost-benefit analysis and multi actor multi criteria analysis: The case of Blackpool and the South Fylde Line. In Decision-making for sustainable transport and mobility. Multi actor multi criteria analysis (pp. 100-119). Cheltenham: Edward Elgar.

17. Dear, M. (1992). Understanding and overcoming the NIMBY syndrome. Journal of the American Planning Association, 58(3), 288-300. https://doi.org/ 10.1080/01944369208975808.

18. Di Ciommo, F., \& Shiftan, Y. (2017). Transport equity analysis. Transport Reviews, 37(2), 139-151. https://doi.org/10.1080/01441647.2017.1278647.

19. Eijgenraam, C. J. J., Koopmans, C. C., Tang, P. J. G., \& Verster, A. C. P. (2000). Evaluation of infrastructural projects; quide for cost -benefit analysis, Sections I and II. The Hague/Rotterdam: CPB.

20. Feiock, R. C. (2010). Regionalism and institutional collective action. In Metropolitan Governance: Conflict, competition and cooperation. Washington: Georgetown University Press.

21. Fiorino, D. J. (1990). Citizen participation and environmental risk: A survey of institutional mechanisms. Science, Technology, \& Human Values, 15(2), 226243. https://doi.org/10.1177/016224399001500204.

22. Flyvbjerg, B. (1998). Rationality and power : Democracy in practice. Chicago: University of Chicago Press Retrieved from https://www.worldcat.org/title/ rationality-and-power-democracy-in-practice/oclc/300447950.

23. Flyvbjerg, B. (2008). Public planning of mega-projects: Overestimation of demand and underestimation of costs. In H. Priemus, B. Flyvbjerg, \& B. van Wee (Eds.), Decision-making on mega-projects (pp. 120-144). Cheltenham: Edward Elgar.

24. Fredriksson, P. G. (2000). The siting of hazardous waste facilities in federal systems. Environmental and Resource Economics, 15(1994), 75-87. https://doi. org/10.1023/A:1008313612369.

25. Frey, R. L. (2003). Regional Governance - zur Selbststeuerung territorialer Subsysteme. Informationen Zur Raumentwicklung, 8/9, 451-462.

26. Gerrits, L. M., \& Teisman, G. (2012). Co-evolutionary planning processes. In G. de Roo, J. Hillier, \& J. Van Wezemael (Eds.), Complexity and planning. Systems, assemblages and simulations (pp. 199-220). Oxon, New York: Routledge.

27. Glasser, H. (1998). On the evaluation of "wicked problems". In Evaluation in planning. Facing the challenge of complexity (pp. 229-249). Dordrecht: Springer Science + Business Media.

28. Healey, P. (1993). Planning through debate: The communicative turn in planning theory. In F. Fischer \& J. Forester (Eds.), The argumentative turn in policy analysis (pp. 233-253). London: Taylor \& Francis.

29. Hickman, R., \& Dean, M. (2017). Incomplete cost - Incomplete benefit analysis in transport appraisal. Transport Reviews, 1-21. https://doi.org/10 1080/01441647.2017.1407377.

30. Hooghe, L., \& Marks, G. (2003). Unravelling the central state, but how? Types of multi-level governance. Reihe Politikwissenschaft, 97(2), 233-243.

31. Innes, J. E. (1995). Planning theory's emerging paradigm: Communicative action and interactive practice. Journal of Planning Education and Research 14(3), 183-189. https://doi.org/10.1177/0739456X9501400307.

32. Jones, P., \& Lucas, K. (2012). The social consequences of transport decisionmaking: Clarifying concepts, synthesising knowledge and assessing implications. Journal of Transport Geography, 21, 4-16. https://doi.org/10, 1016/J.JTRANGEO.2012.01.012.

33. Kębłowski, W., \& Bassens, D. (2017). "All transport problems are essentially mathematical": The uneven resonance of academic transport and mobility knowledge in Brussels. Urban Geography, 3638(June), 1-25. https://doi.org/ 10.1080/02723638.2017.1336320.

34. Leyva-López, J. C., \& Fernández-González, E. (2003). A new method for group decision support based on ELECTRE III methodology. European Journal of Operational Research, 148(1), 14-27. https://doi.org/10.1016/S03772217(02)00273-4.

35. Litman, T. (2002). Evaluating transportation equity guidance for incorporating distributional impacts in transportation planning evaluating transportation equity. World Transport Policy \& Practice, 8(2), 50-65 https:// doi.org/www.vtpi.org/equity.pdf.

36. Lucas, K., Van Wee, B., \& Maat, K. (2016). A method to evaluate equitable accessibility: Combining ethical theories and accessibility-based approaches. Transportation, 43, 473-490. https://doi.org/10.1007/s11116-015-9585-2.

37. Macharis, C. (2005). The importance of stakeholder analysis in freight transport. European Transport / Trasporti Europei, 25-26, 114-126.

38. Macharis, C., Turcksin, L., \& Lebeau, K. (2012). Multi actor multi criteria analysis (MAMCA) as a tool to support sustainable decisions: State of use. Decision Support Systems, 54(1), 610-620. https://doi.org/10.1016/j.dss.2012. 08.008 .

39. Martens, K. (2017). Transport justice. Designing fair transportation systems. New York: Routledge.

40. Marttunen, M., \& Hämäläinen, R. P. (1995). Decision analysis interviews in environmental impact assessment. European Journal of Operational Research, 87(3), 551-563. https://doi.org/10.1016/0377-2217(95)00229-4.

41. Mouter, N., Annema, J. A., \& van Wee, B. (2015). Managing the insolvable limitations of cost-benefit analysis: Results of an interview based study. Transportation, 42(2), 277-302. https://doi.org/10.1007/s11116-014-9539-0.

42. Munda, G. (2004). Social multi-criteria evaluation: Methodological foundations and operational consequences. European Journal of Operational Research, 158(3), 662-677. https://doi.org/10.1016/S0377-2217(03)00369-2.

43. Næss, P. (2006). Cost-benefit analyses of transportation investments. Journal of Critical Realism, 5(1), 32-60. https://doi.org/10.1558/jocr.v5i1.32.

44. Nahmias-Biran, B., Martens, K., \& Shiftan, Y. (2017). Integrating equity in transportation project assessment: A philosophical exploration and its practical implications. Transport Reviews, 37(2), 192-210. https://doi.org/10. 1080/01441647.2017.1276604

45. Nijkamp, P., Rietveld, P., \& Voogd, H. (1990). Multicriteria evaluation in physical planning. Amsterdam: Elsevier.

46. Ostrom, E. (2010). Polycentric systems for coping with collective action and global environmental change. Global Environmental Change, 20(4), 550-557. https://doi.org/10.1016/j.gloenvcha.2010.07.004.

47. Ostrom, V., Tiebout, C. M., \& Warren, R. (1961). The organization of government in metropolitan areas: A theoretical inquiry. The American Political Science Review, 55(4), 831-842. https://doi.org/10.1126/science.151. 3712.868

48. Pahl-Wostl, C. (2009). A conceptual framework for analysing adaptive capacity and multi-level learning processes in resource governance regimes. Global Environmental Change, 19(3), 354-365. https://doi.org/10.1016/j. gloenvcha.2009.06.001.

49. Pereira, R. H. M., Schwanen, T., \& Banister, D. (2017). Distributive justice and equity in transportation. Transport Reviews, 37(2), 170-191. https://doi.org/10. 1080/01441647.2016.1257660.

50. Proost, S., \& Evers, R. (2018). Slimmer onderweg : 25 snelwegen naar een leefbare mobiliteit. Uitgeverij ACCO. Retrieved from https://www.acco.be/nlbe/items/9789463447232/Slimmer-onderweg

51. Rawls, J. A. (1971). A theory of justice. Cambridge: Harvard University Press.

52. Rietveld, P. (2003). Winners and losers in transport policy: On efficiency, equity, and compensation. In D. A. Hensher \& K. J. Button (Eds.), Handbook of transport and the environment (pp. 585-601). https://doi.org/10.1108/ 9781786359513-032

53. Romein, A., Trip, J. J., \& de Vries, J. (2003). The multi-scalar complexity of infrastructure planning: Evidence from the Dutch-Flemish megacorridor Journal of Transport Geography, 11(3), 205-213. https://doi.org/10.1016/ S0966-6923(03)00031-0.

54. Romijn, G., \& Renes, G. (2013). General guidance for cost-benefit analysis. Den Haag: NEl/Ecorys.

55. Rosenhead, J. (1989). Rational analysis of a problematic world. New York: Wiley.

56. Rydin, Y. (2012). Using actor-network theory to understand planning practice: Exploring relationships between actants in regulating low-carbon 
commercial development. Planning Theory, 22-45. https://doi.org/10.1177/ 1473095212455494.

57. Salet, W., Thornley, A., \& Kreukels, A. (2003). Institutional and spatial coordination in European metropolitan regions. In Metropolitan governance and spatial planning. https://doi.org/10.4324/9780203986493.

58. Scharpf, F. W. (1988). The joint-decision trap: Lessons from German federalism and European integration. Public Administration, 66(3), 239-278.

59. Scharpf, F. W. (1997). Games real actors play: Actor-centered institutionalism in policy research. Boulder: Westview Press.

60. Schmitter, P. C. (2010). Governance arrangements for sustainability: A regional perspective. Corporate Governance, 10(1), 85-96. https://doi.org/10. 1108/14720701011021139.

61. Scott, L. (2005). Participatory multi-criteria decision analysis: A new tool for integrated development planning. Development Southern Africa, 22(5), 695716. https://doi.org/10.1080/03768350500364232

62. Stirling, A. (2006). Analysis, participation and power : justification and closure in participatory multi-criteria analysis. Land Use Policy, 23, 95-107. doi: https://doi.org/10.1016/j.landusepol.2004.08.010.

63. Stirling, A., \& Mayer, S. (1999). Rethinking risk. A pilot multicriteria mapping of a genetically modified crop in agricultural systems in the UK. Retrieved from http://users.sussex.ac.uk/ prfh0/Rethinking\%20Risk.pdf.

64. te Boveldt, G. (2019). All aboard? A new evaluation approach for institutionally complex transport projects. Brussels: VUBPress. https://doi.org/10.1016/S02624079(17)31776-1

65. Thomopoulos, N., Grant-Muller, S., \& Tight, M. R. (2009). Incorporating equity considerations in transport infrastructure evaluation: Current practice and a proposed methodology. Evaluation and Program Planning, 32(4), 351-359. https://doi.org/10.1016/J.EVALPROGPLAN.2009.06.013.

66. van Wee, B. (2012). How suitable is CBA for the ex-ante evaluation of transport projects and policies? A discussion from the perspective of ethics. Transport Policy, 19(1), 1-7. https://doi.org/10.1016/J.TRANPOL.2011.07.001.

67. Van Wee, B., \& Molin, E. (2012). Transport and ethics: Dilemmas for CBA researchers. An interview-based study from the Netherlands. Transport Policy, 24, 30-36. https://doi.org/10.1016/j.tranpol.2012.06.021.

68. Verhoef, E. T., Nijkamp, P., Rietveld, P., \& Lakshmanan, T. R. (1997). Benefits and costs of transport classification, Methodologies and policies. Rotterdam: Retrieved from https:/www.econstor.eu/bitstream/10419/85521/1/97084.pdf.

69. Von Winterfeldt, D., \& Edwards, W. (1986). Decision analysis and behavioral research. Cambridge: Cambridge University Press.

70. Wolsink, M. (1994). Entanglement of interests and motives: Assumptions behind the NIMBY-theory on facility siting. Urban Studies, 31(6), 851-866. https://doi.org/10.1080/00420989420080711.

\section{Publisher's Note}

Springer Nature remains neutral with regard to jurisdictional claims in published maps and institutional affiliations.

\section{Submit your manuscript to a SpringerOpen ${ }^{\circ}$ journal and benefit from:}

- Convenient online submission

- Rigorous peer review

- Open access: articles freely available online

- High visibility within the field

- Retaining the copyright to your article

Submit your next manuscript at $\boldsymbol{\nabla}$ springeropen.com 